\title{
Hakoah i Danmark - en undtagelse? En undersøgelse af jødisk idræt i Danmark i perioden 1930 til $1945^{1}$ \\ af Jørn Hansen
}

Den første jøde, der kom mig rigtig nar, var anforeren på kostskolens fodboldhold under okkupationen af Danmark $i$ efteråret 1943. Han hed John, var høj, flot og sortkrøllet og havde et følt, befriende langskud. Det brugte han en dag, da den stedlige tyske kommandant foretog en razzia på skolen. Da Wehrmacht-kortegen kørte bort, sparkede John et behersket skruet skud, der splintrede den forste militarbils forrude. Rektor beroligede den rasende Kapitän - et hoendeligt uheld, ikke sandt. Men for os var John en storre helt end Churchill og Eisenhower tilsammen. En nat nogle uger senere var John og to andre elever forsvundet. Klasselcereren fortalte, at de var hjulpet på flugt fordi tyskerne ville deportere dem til kz-lejr. De var nemlig jфder. Jøder? Jeg havde aldrig skcenket den tanke, at disse danske drenge var jøder.

Denne historie indleder forfatteren og journalisten Poul Hammerichs bog Undtagelsen. En krфnnike om jøderne i Norden frem til 2. verdenskrig. Begivenheden har forfatteren selv oplevet, så beretningen skulle angiveligt være sandfærdig. ${ }^{2}$ Samtidig udsiger beretningen imidlertid også en del om de legender, myter eller sagn, der er blevet tillagt forholdet mellem danskerne og jøderne i nazismens skygge. Indholdet $\mathrm{i}$ disse legender, myter eller sagn beretter, at det $\mathrm{i}$ det moderne Danmark, fra det 20. århundredes begyndelse, var uproblema- tisk at leve som jøde; at såvel den danske befolkning, som dennes repræsentanter $\mathrm{i}$ forholdet til det tredie rige, tog jødernes parti; at jøderne frem til 1943 uantastet kunne fungere i det danske samfund. I det følgende vil disse opfattelser være in mente, når den eneste jødiske idrætsforening $\mathrm{i}$ Danmark undersøges nærmere i perioden fra ca. 1930 til 1945.

\section{Jødisk Idratsforening Hakoah Kobenhavn}

Umiddelbart før slutningen af det 19. århundrede førte den voksende antisemitisme i det såkaldte Mellemeuropa, og den vågnende zionistiske bevægelse sammesteds, til dannelsen af jødiske idræts- og sportsforeninger. I Tyskland blev den første jødiske Turnverein Bar Kochba stiftet i oktober 1898. I Konstantinopel var der allerede dannet en forening i 1895 , men det var fra Berlin, at initiativet udbredtes til de $\emptyset$ vrige Mellemeuropæiske lande. Især i Tyskland, Polen og Østrig-Ungarn, herunder det senere Tjekkoslovakiet dannedes adskillelige jødiske idrætsforeninger. ${ }^{3}$

I begyndelsen af 1920 'erne fandtes der i København enkelte mindre jødiske fodboldklubber, der alle kun eksisterede for en kort periode. Den ganske unge Meyer Rudaizky havde stiftet bekendtskab med disse klubber, men følt sig klemt af de æl- 


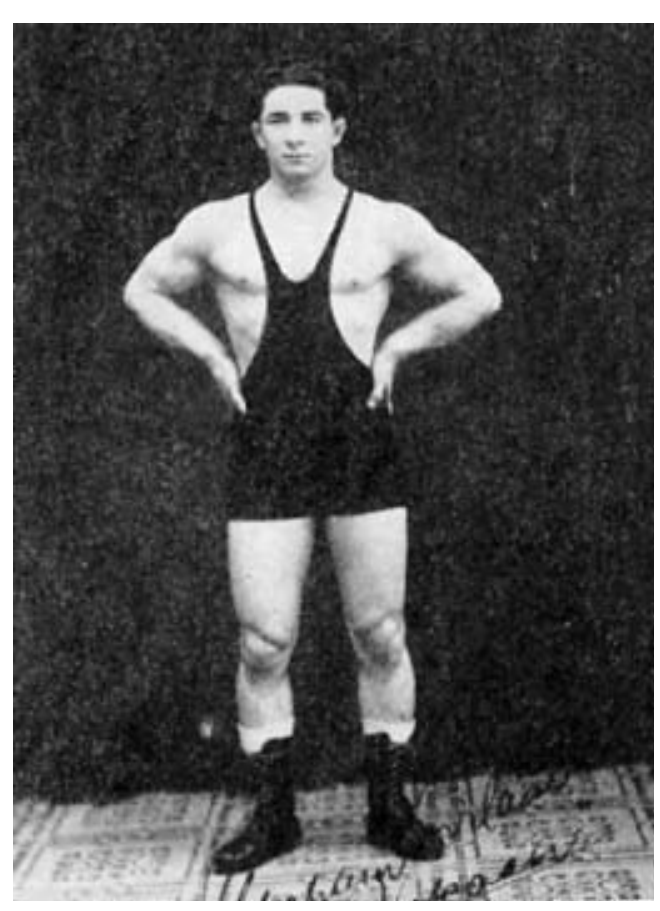

Abraham Kurland.

dre idrætsudøvere. Dette var en afgørende årsag til, at Meyer den 12. februar 1924 grundlagde en jødisk idrætsforening, hvor kammeratskabet skulle være i højsædet. Forbilledet for foreningen var Hakoah Wien, der på dette tidspunkt havde et af Europas bedste fodboldhold og blandt andet havde vundet det $\varnothing$ strigske fodboldmesterskab. ${ }^{4}$ Tankevækkende er det, at samme år som Hakoah på frivillig basis blev dannet som jødisk idrætsforening i Danmark, udelukkede de tyske og østrigske Alpeforeninger, der gav sig af med friluftsliv og skisport, jøder fra deltagelse i deres foreningsliv. Retrospektivt kan man således tale om et varsel for, hvad der måtte komme. $^{5}$

Ved Hakoah start havde man gymnastik og håndbold på programmet, i 1925 begyndte man med fodbold og i 1926 startede brydeafdelingen. Det var brydeafdelin- gen, der førte Hakoah ind på den internationale idrætsscene. I 1927 afholdtes det første brydestævne i København, og hermed lagde man grunden til et utal af brydestævner i løbet af 1930'erne, der må opfattes som Hakoahs idrætslige storhedsperiode. I 1929 vandt den blot 16-årige Abraham Kurland det første Københavnsmesterskab i bantamvægt. Samme år havde man indledt idrætsligt samkvem med jødiske idrætsforeninger i udlandet, og der var blevet etableret en dameafdeling med aktiviteter som gymnastik og håndbold på programmet.

I 1930 blev Hakoah København medlem af Maccabi Weltverband, i 1931 havde man den første brydematch mod den jødiske idrætsforening Maccabi fra Berlin,

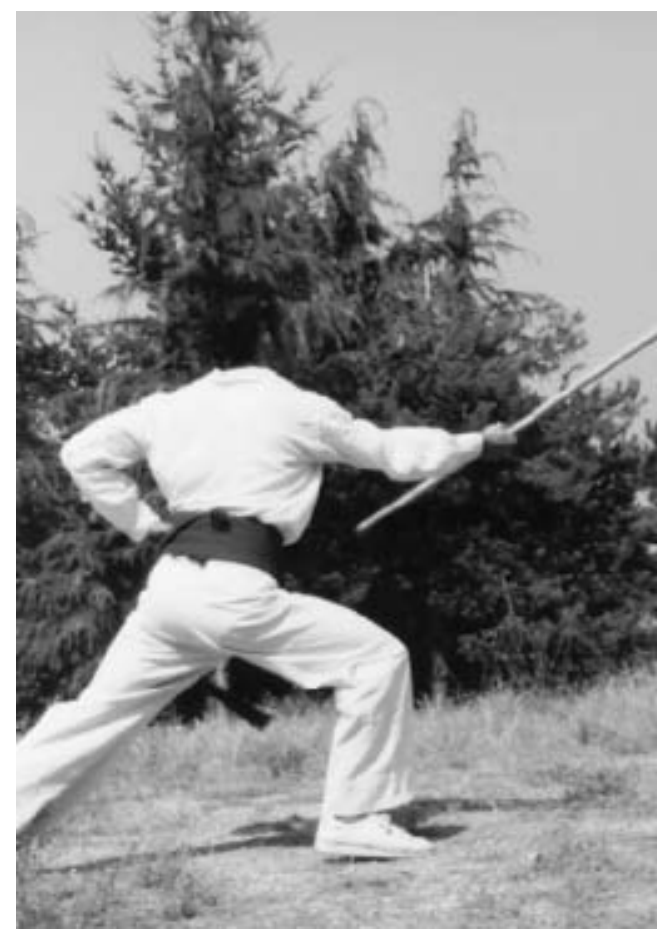

Tel-Aviv 1932. 3 jødiske verdensmestre: Hermann Leiserowitz, Josef Silbermann og Abraham Kurland. 


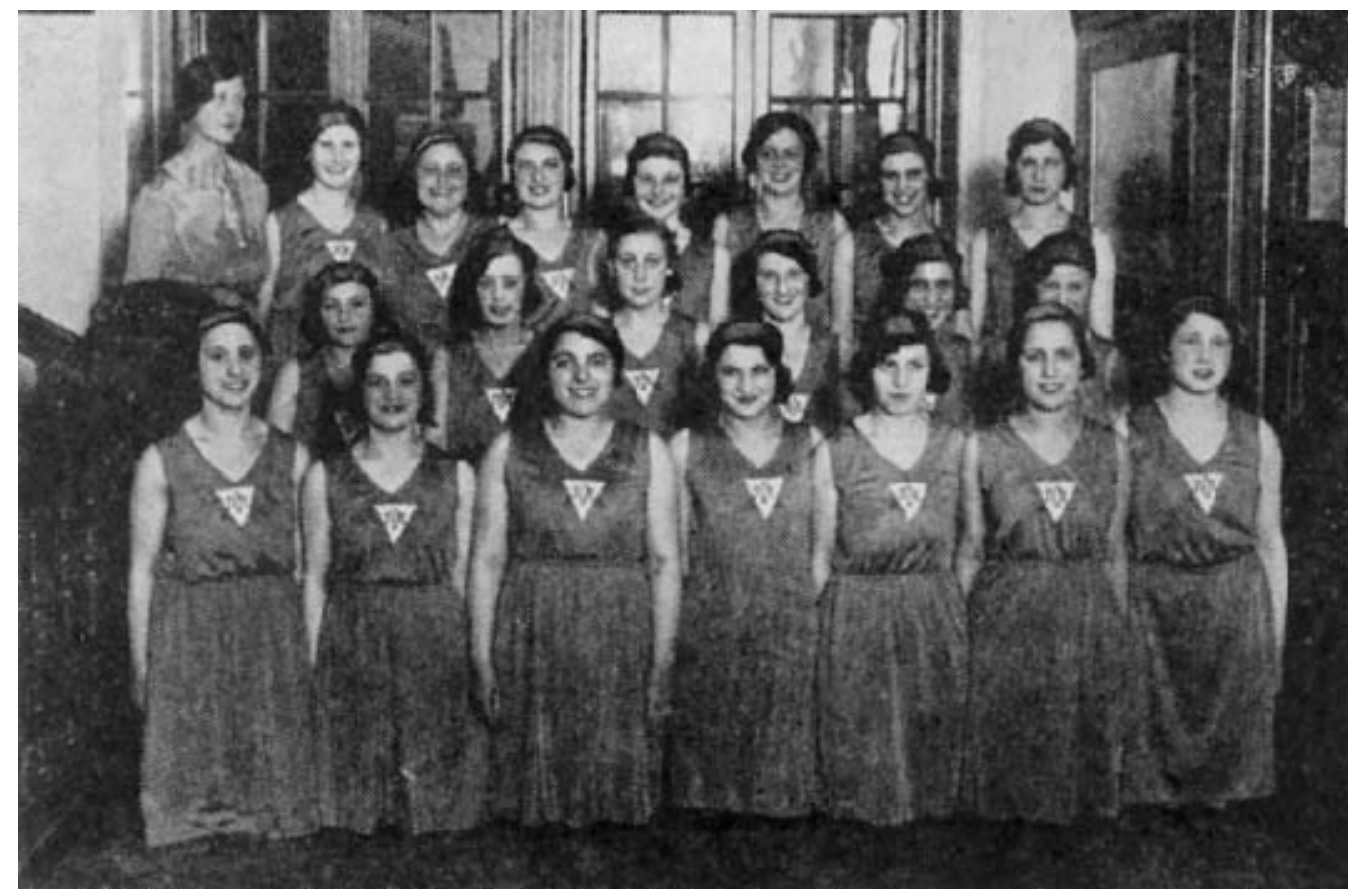

Dame-gymnastikholdet 1932, 1. rakke: R. Raskin, M. Leiserowitz, D. Polano, B. Burstein, S. Heskin, R. Kur, R. Paikin, 2. rakke: P. Melnik, B. Arsernikow, R. Silbermann, G. Kurtik, H. Gwosdin, I. Heskin, 3. rakke: larerinden fru Güldner, E. Grünbaum, M. Boraks, A. Blüdnikow, A. Silberbreandt, A. Boraks, A. Kur, K. Paikin.

hvormed man startede et længerevarende idrætssamkvem med jødiske idrætsforeninger i Tyskland og Østrig. Hakoah København vandt iøvrigt 6-0 i brydematchen mod Maccabi Berlin. ${ }^{6}$

I 1932 sendte Hakoah tre personer til Palæstina for at deltage i den første jødiske Makkabiade, som var det jødiske verdenssamfunds olympiske lege. Midlerne til rejsen derned var skaffet fra Trossamfundet, Danmarks Logen og Zionistforeningen. De tre deltagere var Abraham Kurland, Josef Silbermann og Hermann Leiserrowitz, alle tre stillede op i brydning og vendte hjem som jødiske verdensmestre. Samme år deltog Abraham Kurland på det danske hold ved de olympiske lege i Los Angeles, hvor han vandt sølvmedalje. ${ }^{7}$
De politisk ustabile 30'ere kom til at udgøre kulissen for Hakoah Københavns storhedstid. Brydning blev i offentligheden den aktivitet, der gjorde Hakoah kendt, men alle de andre aktiviteter, såsom gymnastik, fodbold, håndbold, svømning, for en periode boksning og med tiden badminton, trivedes ligeledes i bedste velgående. Selvom man i løbet af 30'erne længe diskuterede, om damerne rent demokratisk kunne være ordinære medlemmer, gjorde kvinderne sig gældende i aktiviteter som gymnastik, håndbold og svømning. ${ }^{8}$ Mest berømmede var Hakoahs internationale brydestævner, og i 1929 dannede Hakoah en selskabelig afdeling, hvormed foreningen kom til at grundlægge en længerevarende tradition for fester, banketter og re- 
vyer, der kunne skaffe midler til idrætsforeningens altid slunkne kasse. I disse fester deltog med tiden prominente personer fra den københavnske offentlighed, nævnes kan Poul Reumert og Børge Rosenbaum, senere kendt i USA under navnet Victor Borge.

Hakoahs forståelse af idræt må siges at være en rimelig traditionel orientering imod konkurrencesporten, foreningen var ved indgangen til 1930'erne medlem af Dansk Idræts-Forbund, der var konkurrenceidrættens hovedorganisation i Danmark, ligesom Hakoah gjorde Dansk Idræts-Forbunds valgsprog »en sund sjæl i et sundt legeme « til sit eget. ${ }^{9}$ Selv om Hakoahs første formand gennem 10 år, Meyer Rudaizky, satte kammeratskabet højt, må det siges, at det eneste der adskilte Hakoah fra andre danske idrætsforeninger med konkurrencesport på programmet var, at det var en lukket forening forbeholdt medlemmer af det jødiske trossamfund.

Uden for Hakoahs idrætsbillede stod aktiviteter som dansen i dens moderne udgave og tankesporten i form af skak. Begge aktiviteter var forbundet med det jødiske samfund i henholdsvis Jødisk Skaklub samt i privat regie $i$ et danseinstitut ledet af en jødisk kvinde. Endvidere var der en større Jødisk Ungdoms-Forening, JUF der indgik $i$ et tæt samarbejde med lignende ungdomsforeninger i Sverige og Norge. Ungdomsforeningen var intellektuel politisk orienteret og syntes på ingen måde i det første årti at samarbejde med Hakoah. Rent organisatorisk var der således tale om en skarp adskillelse af det fysiske og det åndelige i det jødiske samfund. ${ }^{10}$

I realiteten var der tale om en adskillelse inden for det jødiske samfund. Hakoahs stiftere og aktive gennem de første 10 år kom næsten udelukkende fra Østeuropa, populært blev de betegnet som østjøder.
Disse blev ikke umiddelbart velvilligt modtaget af de såkaldte danske jøder, og Hakoah blev en af østjødernes platforme i bestræbelserne på at etablere sig i den jødiske menighed og i det danske samfund. ${ }^{11}$

\section{Hakoah, det jødiske samfund og danskerne}

Set med europæiske øjne kom jøderne relativt sent til Danmark, egentlige jødiske menigheder blev først etableret i slutningen af 1600-tallet, hvor menighederne i Tyskland og Holland allerede var flere hundrede år gamle. Det var i byer som Altona, Glückstadt, Fredericia, Fåborg og København de første små menigheder opstod. Ved indgangen til det 20. århundrede var kun den jødiske menighed i København tilbage. Op gennem 1800-tallet havde man kæmpet en stædig kamp mod den tiltagende assimilation, der havde opslugt menighederne i provinsen. Indvielsen af den nye synagoge i Krystalgade i København i 1833 fik afgørende betydning for bevarelsen af det jødiske samfund, ligesom indvandringsb $\varnothing$ lgerne $\mathrm{i}$ begyndelsen af det 20. århundrede.

Mellem 3 og 4.000 af de russiske jøder, der var på vej til New York, blev hængende i København, hvor de skabte en jiddish-talende kultur i Københavns fattige midtby. Immigranterne gav liv til den hensygnende menighed, men var ikke lige vellidte hos de gamle dansk-jødiske familier, der havde skabt sig en god position i det danske samfund. Ligesom de danske myndigheder så de med bange anelser på de fattige revolutionære trosfæller. Østjødernes historie i Danmark blev imidlertid en succeshistorie. I løbet af blot 15-20 år havde de forbedret deres situation så meget, at de kunne etablere sig i arbejderkvarterer på Københavns 
Nørrebro. Efter 15 år i landet opnåede de fleste dansk statsborgerskab. Og de, der endnu ikke var sikret økonomisk og socialt, kunne få gavn af de danske socialreformer fra 1930'erne. ${ }^{12}$

Den næste indvandringsbølge kom i 1930'erne - samtidig med Hakoahs storhedstid - og udgjordes hovedsageligt af jøder på flugt fra det nazistiske regime. De danske myndigheder fastlagde en restriktiv flygtningepolitik, der førte til afvisning af utallige tyske jøders ansøgninger om asyl eller om blot at komme ind i landet. Nøjagtige angivelser af antallet af afviste findes ikke, men ofte anslåes det til at være omkring halvdelen af de, der bankede på døren til Danmark. I alt kom der ca. 4.500 jøder fra Hitlers Tyskland, Østrig og Tjekkoslovakiet i perioden efter 1933.

Da 2. verdenskrig brød ud var der ca. 8.000 jøder i Danmark, udover de »gamle« jøder og østjøderne udgjordes disse af jøder på flugt fra Hitler, hvoraf der den 9. april - dagen for Danmarks besættelse stadig var 1500 tilbage. Flygtningene var ilde stedte, de var hverken accepterede af de danske myndigheder eller af den jødiske menighed i Danmark. ${ }^{13}$ Blandt jøderne i Danmark i 1930'erne udgjorde de ca. 800 mænd, der havde fået tilladelse til at uddanne sig til landbrugselever (chalutzim) før de emigrerede til Palæstina, en særlig gruppe. Deres forbindelse til idrætshistorien vil blive omtalt senere.

Det er indlysende, at tilstrømningen af jødiske indvandrere til Danmark måtte sætte sine spor. I »Jødisk Familieblad« fra september 1933 greb en af de ældre danske jøder da også pennen for at opponere mod en ny foreningsdannelse »Brith Habonim«, som skulle være en aflægger af det tyske forbund af samme navn. Initiativet blev mødt af følgende salve:

De Mennesker, der er kommet med saa- dant et Forslag, er antagelig ikke klar over, hvor megen Skade, de kan udrette hermed. I den nye Forenings program novnes, at »et vardigt jødisk Liv for os kun er muligt med Bekraftelse af den Kendsgerning, at vi er Jфder indenfor Rammerne af et jodisk Fallesskab«. De danske Jøder har dog netop vist, at et »vardigt jødisk Liv« kan leves udenfor de foreslaaede Rammer af et jфdisk Fallesskab..... Det kan heller ikke kaldes sarlig »vardigt «at besvare dansk Imødekommethed med Sardannelser baade i Tide og Utide.

Og hvad betyder al denne Snak om »en ny sund jodisk Mennesketype forbunden med Naturen «. De danske J $\phi$ der kan faa og faar al den Luft, de maatte фnske sig. Jøder er lige saa velkomne som andre Mennesker $i$ Det Danske Spejderkorps, i Fodbold-, Tennis-, Svфmme-, Ro- og andre Idratsklubber, paa Badestrande og Badeanstalter, $i$ Gymnastikforeninger og alle andre Steder, hvor Sundheden kan dyrkes, ...

... det er da ogsaa betegnende, at to af det nye Blads tre Redaktionsmedlemmer er Indvandrede, der ikke kan have de forn $\phi d-$ ne Forudsatninger for at forstaa danske Forhold ... naar vi her $i$ Beskedenhed har varet $i$ Stand til at modtage udenlandske J $\phi d e r$, hvad enten det har varet Flygtninge eller andre, skyldes det, at de danske J $\phi d e r$ har forstaaet, hvorledes man skal assimilere sig i Danmark. Erfaringerne i Tyskland tyder ikke paa, at de der anvendte Former med at holde sig for sig selv paa Alverdens omraader virker beroligende paa Omgivelserne. ${ }^{14}$

Uenighed mellem de nyligt indvandrede jøder og de gamle danske jøder understreges i den videre debat. En af initiativtagerne til »Brit Habonim« Nath. Skorochod formulerede i sit svar til Ove Nathan blandt andet følgende: Den Stilling, J $\phi d e r-$ ne $i$ Alverdens Lande har indtaget og sta- 
dig indtager, gør mig endnu starkere i mit Standpunkt. Jødernes Skabne er falles, for mig eksisterer der ingen Forskel paa danske Jøder og udenlandske. ${ }^{15}$ Nath. Skorochod var i 1930 blevet associeret Hakoahs bestyrelse som en form for repræsentant for Maccabi Weltverband, der repræsenterede et entydigt zionistisk synspunkt. ${ }^{16}$

Flere i debatten betonede de danske jøders særstatus i modsætning til jøderne i andre lande: Medens Indvandringen af $\emptyset$ stjøder $i$ Tyskland fik den gamle Antisemitisme til at koge over, saa er Østjøderne $i$ Danmark kommet til et Land med ringe eller ingen Antisemitisme, til et land uden et J $\phi$ despørgsmål og hvor J $\phi$ de ikke er noget Skceldsord. Maatte I unge Fremmede forstaa dette og bidrage til at dette ikke andres. ${ }^{17}$

Diskussionen om assimilation eller ej førte også til en overordnet diskussion om jødiske foreninger i det hele taget. For Hakoahs vedkommende var der de første år og ind i 1930'erne en diskussion om, hvorvidt en jødisk idrætsforening havde en berettigelse i et frit land som Danmark, hvor hvem som helst var velkommen i en hvilken som helst forening, uden hensyn til race eller religion. Hakoah holdt selvfølgelig på, at foreningen havde en berettigelse i og med, at den bedre end nogen anden havde forudsætninger for at samle den jødiske ungdom, som normalt ikke ville melde sig ind i nogen idrætsforening til udøvelse af udviklende idrat, hvilket atter, gennem at beskaftige de unge i deres fritid, borteliminerer den lediggang, som kan vare roden til meget ondt. ${ }^{18}$

For at sikre Hakoah en bedre platform i den jødiske menighed indbød bestyrelsen i 1934 rabbiner Marcus Melchior til et møde, hvor man diskuterede »Foreningens Trivsel paa det kulturelle Omraade«. Ved mødet udtrykte Marcus Melchior stor sym- pati for Hakoahs arbejde og beklagede »at Hakoah ikke havde fået mere Stotte fra Menighedens side end Tilfaeldet er..«. Melchior foreslog også, at Hakoah skulle slutte sig sammen med to andre jødiske ungdomsforeninger, af protokollen fremgår dog ikke hvilke. Dette $\varnothing$ nske kunne bestyrelsen imidlertid ikke imødekomme. ${ }^{19}$ Men fra da af var der etableret et godt forhold mellem Hakoah og resten af den jødiske menighed.

Hakoahs succes på det idrætslige område har givetvis også spillet en betydningsfuld rolle for foreningens fortsatte eksistens. Af en gennemgang af henholdsvis Jødisk Familieblad samt Mosaisk Samfunds meddelelses- og debatblad for perioden fremgår det, at Hakoah København gennemløber en udvikling fra lavstatus til en mere central placering i den jødiske offentlighed. I de første 5-6 år af foreningens virke omtales denne næsten ikke i bladene. Fra 1931 får Hakoah fast spalteplads under rubrikken »Sport« i bladet Mosaisk Samfund. Organ for det Mosaiske Familie og Forretningsliv i Danmark. En rubrik, der havde afgørende betydning for Hakoah, i og med foreningen på dette tidspunkt ikke havde noget medlemsblad. Første medlemsblad udkom under navnet Hakoahneren i 1942, men fik i sagens natur i første omgang en kort levetid.

Hakoahs mere centrale placering i det jødiske samfund i København fremgår blandt andet af en artikel i Jødisk Familieblad fra 1937, hvor M.M. (signaturen for rabbiner Marcus Melchior) diskuterede, om der var for mange foreninger i det jødiske samfund. Det var M.M.'s opfattelse, at nogle foreninger syntes overflødige og burde opløses, imidlertid var der også enkelte foreninger, der ofte blev udsat for angreb, som i høj grad havde deres eksistensberettigelse: 
Vi toenker særligt paa »Hakoah«, Sportsforeningen med de mange Hundrede Medlemmer, med de vellykkede Sportsstcevner og de fremragende Sportsnavne. Her er et af Punkterne, hvor Tampen brander, og $i$ vide Kredse billiger man ikke, at der overhovedet eksisterer en jødisk Sportsforening. Jeg synes, at Angrebene er uberettigede, og at de burde forstumme . Hakoah" nyder overordentlig Anseelse i dansk, ja i nordisk Sportsliv. Den er trods dens jødiske sarprag, anerkendt som en dansk Sportsklub af Rang. Det ligger noert at antage, at de unge jødiske Sportsfolk, der under »Hakoah«s Marke har tilkampet sig saa mange arefulde Sejre, Sejre, der i det vasentlige er kommet dansk Sport til Gode, ikke vilde have kunnet yde det samme, om de havde varet Medlemmer af de andre Foreninger. ${ }^{20}$

På denne måde - i form af rabbineren tilkendegivelser - fik Hakoah således det jødiske samfunds officielle støtte.

\section{Hakoah og Det tredie Rige - Berlin 1936}

I 1931 havde Hakoah for første gang haft idrætssamkvem med jødiske idrætsforeninger fra Tyskland, et samarbejde der fortsatte op igennem 1930'erne. Så sent som i 1938 spillede Hakoahs fodboldafdeling i Hamborg mod den jødiske klub »Blau Weiss «. Hvordan så man i Hakoah og den jødiske menighed på det fortsatte idrætssamarbejde med foreninger i Tyskland?

Ud over en større diskussion vedrørende deltagelsen i de olympiske lege i Berlin 1936, blev der i 1934 fors $ø$ gt startet en mere generel diskussion om samarbejde med jødiske idrætsforeninger i Tyskland.

Udgangspunktet for diskussionen var et forsøg på at hverve professionelle jødiske boksere i Danmark til et stævne i Berlin. En anonym skribent problematiserede denne begivenhed, da: Der er tusind andre Steder, man hellere vil bokse end $i$ det tredie Rige. ${ }^{21}$

I et senere nummer af Mosaisk Samfund trådte Hermann Lejserowitz frem som den, der i forbindelse med Hakoahs bokseafdeling havde modtaget henvendelsen fra formanden for Maccabi i Berlin. Det var Lejserowitzs opfattelse, at man skulle

opfordre alle jødiske Idrctsorganisationer i forskellige Lande om at pleje saa megen Samkvem med de jødiske Idratsmand $i$ Tyskland som muligt. Ved at invitere dem og selv lade sig invitere til jødisk-arrangerede Sportsstcevner til Opmuntring af vore tyske jødiske Kammerater. De kan have det haardt nok $i$ det daglige liv. ${ }^{22}$

I forbindelse med Hermann Lejserowitzs artikel opfordrede Mosaisk Samfund til en generel diskussion om, hvorvidt jødiske idrætsmænd burde have noget med det Tredje Rige at gøre. Debatten blev aldrig principiel, dertil var de forholdsvis få indlæg, der blev bragt i bladet, af al for polemisk og personlig karakter. Enige var man langt fra, enkelte ville kun tage til Tyskland, hvis Hitler personligt ville stille op i en boksekamp mod dem!23

Blandt andet diskussionens karakter gjorde en principiel afklaring umulig. Praksis blev således bestemmende. I efteråret 1934, umiddelbart efter diskussionen i Mosaisk Samfund, spillede Hakoah en fodboldkamp mod Hagiba Berlin, idrætssamkvemmet med jødiske idrætsforeninger i Det Tredie Rige fortsatte således.

Mere principiel blev diskusionen om Hakoahs deltagelse i de olympiske lege i Berlin. Selve diskussionen derom startede ikke i Mosaisk Samfund, men i det kommu- 
nistiske Arbejderbladet og iblandt de såkaldte kulturradikale, der lagde op til, at kunstnere fra Danmark skulle nægte at deltage i de Kunstnerlege, der var integreret $\mathrm{i}$ de olympiske lege i Berlin 1936. ${ }^{24}$

I Arbejderbladet fra den 23. maj 1935 bragte man et interview med Hakoahs formand Marcus Schwartzmann, der blev forespurgt, om Hakoah ville deltage i de olympiske lege: Ja selvfølgelig, svarer Herr Marcus Schwartzmann uden Betcenkning, hvorfor skulle vi ikke det? Vi er en upolitisk Klub og фnsker ikke at drive Politik. I samme udgave af Arbejderbladet citeres OL-kandidaten Abraham Kurland for, at han hele tiden havde tænkt sig ikke at deltage i Berlin 36, men at det iøvrigt var en sag klubben afgjorde.

Artiklen i Arbejderbladet fik Mosaisk Samfund til at reagere. Igennem adskillige uger kørte debatten i bladet. Andre Jødiske Foreninger tog skarpt afstand fra formanden for Hakoahs synspunkter, og med tiden rejstes en decideret protestaktion i den jødiske menighed i Danmark. ${ }^{25}$

Hakoahs formand Marcus Schwartzmann uddybede sit synspunkt i Mosaisk Samfund nr. 25 og var, hvad dette angår, på linie med IOC's opfattelse af ikke at blande politik og idræt. Han vill kun se på sagen ud fra en rent sportslig tilgang:

og det er mig derfor ligegyldigt om Legene afholdes $i$ Tyskland, Brasilien eller Kina, jeg vil betragte det som en stor Ere, dersom en eller flere af »Hakoah«s Medlemmer kom til at reprasentere Danmark...... personligt kan jeg som Jøde, paa det kraftigste protestere og misbillige den grusomme Uret, der фves overfor Jøderne fra Nazis side; men det maa ikke give sig udslag $i$ en offentlig Protest, naar jeg $m \phi$ der som dansk Sportsreprasentant, udsendt af de danske Sportsorganisationer for at reprasentere Danmark. ${ }^{26}$
Selvom Schwartzmann nuancerede sine synspunkter, kom Hakoahs bestyrelse til at stå alene med sine synspunkter. Ved generalforsamlingen i 1935 besluttede man sig for at afvente andre landes jødiske idrætsforeningers synspunkter. Tilsidst, efter Maccabi-Verdenskongres-beslutningen, bestemte man sig for ikke at deltage, og gik hermed givetvis glip af en medalje til Abraham Kurland.

Den endelige beslutning herom blev truffet på generalforsamlingen den 31 . marts 1936. Presset hertil blev man ikke blot af det jødiske samfund i Danmark, men i høj grad også af arbejderidrætten i forbundet Dansk Arbejder-Idræt, hvis ledere var organiserede socialdemokrater. Hakoah var som nævnt organiseret i Dansk Idræts-Forbund. Sammen med Danmarks Olympiske Komité sendte forbundet medlemmer til Berlin 36. Hakoah var den eneste medlemsforening, der boykottede legene i Berlin. Medlemmer af Dansk Arbejder-Idræt stod uden for Dansk Idræts-Forbund og havde hele tiden talt imod legene $\mathrm{i}$ Berlin. ${ }^{27}$

Schwartzmann bevarede trods sine synspunkter sit formandsskab frem til 1937 populær blev han aldrig i spalterne i Mosaisk Samfund. I 1937 blev han afløst af den noget yngre A. Schønbaum, der blev hilst velkommen af såvel Jødisk Familieblad som Ugebladet for Mosaisk Samfund. I 1938 valgte Hakoahs fodboldafdeling at organisere sig i Dansk Arbejder-Idræt. ${ }^{28}$

\section{Chalutzim (landbrugselever) - hфjskole og gymnastik}

Uafhængigt af Hakoah foregik der i perioden fra 1933-40 et vellykket stykke jødisk hjælpearbejde med et idrætsligt islæt. Centralt i denne sammenhæng stod blandt an- 
det vinhandler Binjamin Slor, der medvirkede til, i løbet af de omtalte syv år, at skaffe et større antal unge jøder en landbrugsuddannelse i Danmark. Binjamin Slor voksede op i en landsby nord for TelAviv og dannede som 18-årig, sammen med nogle kammerater, i 1910 en militant sporstklub Maccabi, der skulle medvirke til at styrke de unge menneskers fysiske kunnen, så de bedre kunne modstå eventuelle arabiske overfald.

Det var tanken, at Binjamin Slor skulle uddannes til gymnastiklærer, hvorfor han blev sendt til København, hvor gymnastikinspektør K.A. Knudsen fik ham optaget på Statens Gymnastikinstitut som den første udlænding. Efter 1. verdenskrig blev hans datter elev på Ollerup Gymnastikhøjskole, hvor navnkundige Niels Bukh var forstander. Gennem højskolebevægelsen fik Slor relationer til det danske landbrug, for da Slor kom i kontakt med Ollerup havde ca. 300.000 danske landboere over tre generationer været på højskole. Det lykkedes Binjamin Slor, sammen med Julius Margolinsky fra det jødiske samfund i København og lederen af Landøkonomisk Rejsebureau Niels Siggaard, at få en del gymnastikfolk fra Palæstina oplært i Danmark. Med tiden udbredtes initiativet gennem højskolesystemet over det ganske land. Klientellet kom hovedsageligt fra Tyskland, Østrig, Tjekkoslovakiet og Polen. I alt 1450 fik uddannelsen, 1000 nåede til Palæstina, medens ca. 400 stadig var i Danmark den 9. april 1940. ${ }^{29}$

Binjamin Slors ophold i Ollerup, samt jødernes gode forbindelser til højskolebevægelsen kan forklare det paradoksale, at forstander Niels Bukh trods sine stærke nazi-sympatier og nazi-racistiske synspunkter bevarede et gensidigt godt forhold til det jødiske samfund i Danmark. I de jødiske blade opfordredes de unge jøder adskillige gange til at tage ophold på Ollerup Gymnastikhøjskole. Og så sent som i juni 1939, hvor Niels Bukhs nazi-sympatier var velkendte, men efter en indgriben fra statsministeriel side mere afdæmpede, stod denne i spidsen for en storstilet gymnastikopvisning til fordel for landflygtige jødiske børn. ${ }^{30}$

\section{Hakoah under Danmarks bescettelse}

Den 9. april 1940 rullede tyske tropper ind over den dansk-tyske grænse, og besættelsen af Danmark og Norge blev hurtig en realitet. I Danmark kom det kun til sporadiske kampe, regeringen gav op over for den militære overmagt og indledte af hensyn til befolkningen en samarbejdslinie med besættelsesmagten. Et samarbejde, der varede frem til folkeopstanden i august 1943.

Som et resultat af samarbejdslinien greb besættelsesmagten i første omgang ikke ind over for foreningslivet i Danmark, der i det hjemlige kunne fortsætte som hidtil. Mere problematisk var det selvfølgeligt med det internationale idrætssamkvem, hvor blot det neutrale Sverige og besættelsesmagten Tyskland fremstod som mulige samarbejdspartnere. Dansk Idræts-Forbund var i første omgang afvisende over for et samarbejde med Tyskland, men blev presset dertil af regeringens samarbejdslinie. $^{31}$

Hakoah kunne udelukkende samarbejde med idrætsforeninger i Danmark, som jøder kunne de efter besættelsen ikke forvente at få udrejsetilladelse. Umiddelbart efter besættelsen var Hakoah i en afventende position, den varslede generalforsamling den 16. april blev udsat, men forholdsvis hurtigt blev det klart, at Hakoah ligesom 


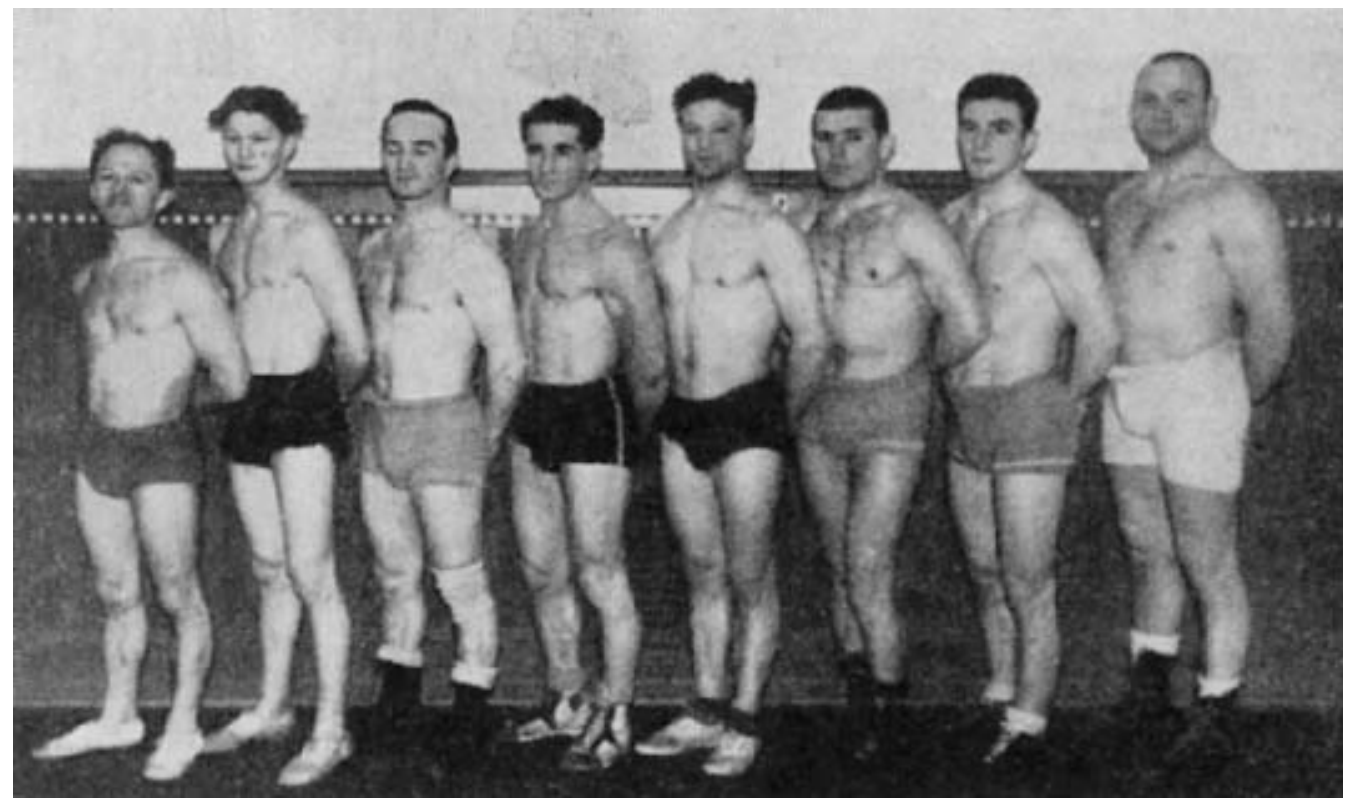

Foreningens mesterhold, der vandt holdturneringen 1941. Fra venstre: Hermann Leiserowitz, Kolle Leiserowitz, Michael Kurland, Abraham Kurland, Jacob Leiserowitz, Leo Toron, Emanuel Simakoff, Isak Paikin.

andre idrætsforeninger i Danmark fik lov til at fortsætte sit virke. ${ }^{32}$

De ydre omstændigheder styrkede arbejdet indadtil, i 1941 blev Hakoahs brydeafdeling for første og eneste gang Danmarksmester. De fleste afdelinger i Hakoah oplevede en $\varnothing$ get medlemstilgang og Hakoah voksede til at blive Nordens største jødiske idrætsforening, kulminerende med 374 medlemmer i sæsonen $1942 / 43 .{ }^{33}$ Især havde man intensiveret arbejdet med børn og unge.

I 1942 udkom som tidligere omtalt foreningens første medlemsblad Hakoahneren. Bladet skulle angiveligt skabe en bedre kontakt med Foreningens medlemmer, men hensigten var også, da andre jødiske blade ikke længere var tilladte, at optage Bidrag af forskellig Art, som også kunde have Interesse for Foreningens $\phi v r i g e$ Medlemmer. Enhver Artikel af lodig Ka- rakter vil blive optaget..$^{34}$ Hakoahs aktiviteter fik også et bredere perspektiv, ud over revyer og fester tog Hakoah initiativ til arrangementer med oplæsning ved skuespillere, foredrag vedrørende seksualoplysning, foredrag af overrabineren og foredrag vedrørende Palæstina for blot at nævne nogle.

I 1943 startede Hakoah en byggefond, der skulle arbejde for at skabe et samlingssted for hele den jødiske ungdom i Danmark, et Sted, hvor den kan tilbringe sin Fritid med sund Idrat eller i Selskab med gode Venner og Bekendte. ${ }^{35}$ Byggefonden omtaltes i Hakoahneren's septembernummer 1943. Hvor man ligeledes drøftede, om Abraham Kurland i modsætning til tidligere ville kunne få udrejsetilladelse, så han kunne stille op for det danske landshold i brydning i kampen mod Sverige. I samme blad kunne man også læse om et 
større planlagt arrangement i Odd-FellowPalæets store sal den 3. oktober et arrangement $i$ et Format der ikke for er oplevet $i$ vore Kredse. Et arrangement, der aldrig blev afholdt.

Den 29. august 1943 indvarsledes en folkeopstand afslutningen på regeringens samarbejdspoltik med tyskerne. Det jødiske samfund i Danmark var imidlertid af den opfattelse, at tyskernes ord om ikke at røre de danske jøder stadig ville stå ved magt. Den 28. september 1943 opsøgte attachéen for søfartsanliggende ved den tyske legation imidlertid socialdemokraten, senere statsminister, Hans Hedtoft for at meddele denne, at man ville deportere de danske jøder.

Dette blev startskuddet til en storstilet redningsaktion af de ca. 8.000 jøder der fandtes i Danmark. Da tyskerne startede aktionen, var de fleste jøder gået under jorden eller på vej til Sverige. I løbet af de næste 14 dage lykkedes det at få langt de fleste jøder bragt i sikkerhed i Sverige, blot 472 blev interneret. ${ }^{36}$

I august 1945 holdt Hakoah igen sit første møde på dansk jord. ${ }^{37}$ I 1999 kan foreningen fejre sit 75-års jubilæum.

\section{Noter}

1. Artiklen er en bearbejdet udgave af det foredrag, forfatteren holdt ved den internationale konference Jüdischer Sport und jüdischer Gesellschaft Berlin 21-23 oktober $1998 \mathrm{i}$ anledning af 100-året for stiftelsen af den første jødiske idrætsforening i Berlin.

2. Se Paul Hammerich: Undtagelsen - En krønike om jøderne i Norden frem til 2. verdenskrig. Gyldendal 1992. Det er i dag umuligt at afklare, om den af Hammerich beskrevne situation reelt var selvoplevet - der er en del unøjagtige oplysninger i værket iøvrigt (se en senere note). I denne kontekst er det imidlertid ikke så afgørende, da Hammerich gennem den fortalte historie om fodboldsparket eksemplarisk bygger videre på myten om situationen for de danske jøder under krigen.

3. Se hertil programmet for symposiet Jüdischer Sport und jüdischer Gesellschaft, Berlin oktober 1998.

4. Festskrift i anledning af Hakoah's 25 års jubilæum, redigeret af Pinius Solovej, 1949.

5. Jvf. Rainer Amstädter: Deutsche Berge, arische Hütten. Die Ghettoisierung des jüdischen Alpinismus im Deutschland und Österreich de Zwischenkriegszeit. I: Jüdischer Sport und jüdischer Gesellschaft Kurzfassungen p. 6.

6. Se Hakoah 25 år opus cit.; Jødisk Idrætsforening 40 år, udvidet nummer af Hakoahneren 1964; Jubilæum's Hakoahneren 1974; Hakoah 60 år, redigeret af Dan Melchior og Allan Rosenbaum 1984; JIF Hakoah 70 år, redigeret af Elon Cohn 1994.

7. Hakoah 25 år.

8. Se hertil diskussionen i bestyrelsen i Hakoahs protokol 1929-1949.

9. Hakoah 25 år.

10. Se hertil Jødisk Familieblad, Kbh. og Mosaisk Samfund, Kbh.

11. Dette kan kun inddirekte læses ud af kildematerialet og vil fremgå af det næste afsnit. At det udelukkende var Østjøder, der stod bag etableringen af Hakaoh, er imidlertid blevet bekræftet gennem en samtale med en af Hakoahs tidligere formænd Arne Bodnia.

12. Se Det Mosaiske Troessamfund. Det jødiske samfund i Danmark, udgivet af Det Mosaiske Troessamfund, redigeret af John Dessau m. fl. 1996

13. ibid.

14. Ove Nathan: Et nyt Jødisk Ungdomsblad. I: Jødisk Familieblad 6. Årgang Nr. 1 1933, s. 1314.

15. Jødisk Familieblad 6. Årg. Nr. 3 1933, s. 10.

16. Se hertil Hakoahs protokol 1929-1949.

17. Frans Henriques: Et Ord inden det er for sent. I: Jødisk Familieblad 6. Årg. Nr. 5 1933, s. 12.

18. Hakoah 25 år opus cit., s. 8.

19. Hakoahs protokol 1929-1949, s. 117.

20. Jødisk Familieblad 11. Årg. Nr. 4 1937, s. 5.

21. Mosaisk Samfund nr. 221934.

22. Mosaisk Samfund nr. 241934.

23. Mosaisk Samfund nr. 25, 26 og 271934.

24. Se hertil Jørn Hansen: Hellere en Sild uden Rogn end en Akilles, hvis Hjerne sidder i hans Albuer - 
De olympiske lege i Berlin 1936 og diskussionen herom i Danmark. I: Idrætshistorisk Årbog 1993 , Odense Universitetsforlag.

25. Mosaisk Samfund nr. 24, 25, 26, 27 og 281935.

26. Mosaisk Samfund nr. 251935.

27. Jørn Hansen opus cit. samt Hakoahs Protokol 1929-1949, s. 154.

28. Mosaisk Samfund ændrede i 1936 navn til Ugebladet for Mosaisk Samfund.

29. Se Paul Hammerich opus cit s. $293 \mathrm{ff}$. I sin beskrivelse af Binjamin Slors adfærd er Hammerich unøjagtig. Hammerich angiver, at det var Slor selv, der havde været på Ollerup, men ifølge Hans Bondes gennemgang af Bukhs forhold til jøderne var det datteren, der havde haft et ophold på Ol- lerup, jvf Jødespørgsmålet i disputatsmanus fra Hans Bonde in print.

30. Se hertil Ugeblad for Mosaisk Samfund nr. 24 1939 samt Hans Bonde ibid.

31. Se Per Jørgensen: DIF under 2. verdenskrig. I: Else Trangbæk, Jørn Hansen, Niels Kayser Nielsen (red.): Dansk Idrætsliv Bd. 2 Gyldendal 1995.

32. Se Hakoahs protokol 1929-1949.

33. Hakoahneren nr. 101943.

34. Hakoahneren nr. 11942.

35. Hakoahneren nr. 151943.

36. Poul Borchenius: Spredt blandt folkeslagene. Bind 4: Historien om de danske Jøder. Fremad 1969, s. $287 \mathrm{ff}$.

37. Hakoahs protokol 1929-1949. 